\title{
Patentu īpašuma ǵenēze un attīstības perspektīvas
}

\author{
Andris Šḳesters \\ Rīgas Stradina universitāte, Doktorantūras nodaḷa, \\ Doktora studiju programma "Juridiskās zinātnes", Latvija \\ Andris.Skesters@rsu.lv
}

\section{Kopsavilkums}

Rakstā "Patentu īpašuma genēze un attīstības perspektīvas" ir sniegts ieskats patentu ỉpašuma izveidē un vēsturiskajā attīstībā, kā arī akcentētas mūsdienu attīstības tendences patentu īpašuma jomā.

Ir sistematizēti patentu īpašuma attīstības vēsturiskie posmi, kā arī akcentēti apstākḷi, kas mainījuši patenta īpašuma izpratni.

Rakstā analizēta patentu īpašuma aizsardzības sistēmu izveide un to īpatnības, kā arī kolīziju risinājumi patentu īpašuma jomā, kas rodas, ja viena valsts ir uzṇēmusies saistības vairākos starptautiskos līgumos. Akcentēta arī morāles un ètikas normu nozīme patenta īpašuma jomā, kā arī ar piemēriem no tiesu prakses pārliecinoši parādīta morāles un ètikas normu nozīme patenta īpašuma atzī̌̌anā.

Atslēgvārdi: ētika, īpašums, patents, tiesību unifikācija.

\section{levads}

Rakstā ir sniegts ieskats patentu īpašuma genēzē un mūsdienu attīstības tendencēs patentu īpašuma jomā, sistematizēti patentu îpašuma vēsturiskās attīstības posmi, kā arī analizēti apstākḷi, kas veicinājuši patenta îpašuma izpratnes attīstību noteiktos laika posmos.

N̦emot vērā patentu īpašuma saikni ar konkrētu teritoriju, rakstā ir analizēta arī patentu aizsardzības sistēmu izveide, kas ir būtiski ietekmējusi patenta īpašuma izpratni un veicinājusi patentu îpašuma tiesiskā regulējuma unifikāciju un harmonizāciju, kā arī sniegts ieskats vairāku patentu īpašuma tiesību aizsardzības sistēmu - Eiropas patentu tiesību sistēmas - Eiropas Savienības patentu tiesību sistēmas - Pasaules Tirdzniecības organizācijas patentu tiesību sistēmas - izveidē. 
Vairāku patentu aizsardzības sistēmu izveide ir radījusi kolīzijas patentu īpašuma aizsardzības jomā. Turklāt mūsdienu aktualitātes patentu īpašuma jomā ir saistāmas ne tikai ar patenta īpašuma teritoriālajiem aspektiem, bet arī ar morāles un ētikas apsvērumiem, kas sniedz pamatojumu patenta īpašuma pastāvēšanai. Vienas valsts saistības vairāku starptautisko konvenciju ietvaros un vienas valsts dalība vairākās starptautiskajās organizācijās rada nepieciešamību risināt radušās kolīzijas ne tikai patentu îpašuma teritoriālajā aspektā, bet arī izvirza jautājumus, vai noteiktu izgudrojumu izmantošana vispār ir piel̦aujama.

Pētniecības metodes: vēsturiskā pētniecības metode ir izmantota, lai parādìtu patenta īpašuma izpratnes attīstību laika gaitā; salīdzinošā pētniecības metode - lai parādītu atšķirības dažādās patentu aizsardzības sistēmās. Ar indukcijas palīdzību ir izdarīti secinājumi par patentu aizsardzības sistēmas pilnveidi, ņemot vērā tiesu praksē un tiesību doktrīnā paustās atziṇas. Dedukcija izmantota, lai izdarītu secinājumus par patentu īpašumtiesību regulējuma pilnveidi, n,emot vērā pārmaiņas sociāli ekonomiskajos apstākḷos.

\section{Svarīgākās atziṇas teorijā un praksē}

\section{Patentu ĩpašuma izcelsme}

Romiešu civiltiesībās nebija intelektuālā īpašuma jēdziena un arī patentu īpašuma jēdziena. Atbilstoši romiešu īpašuma tiesību regulējumam tikai viena persona varēja būt lietas īpašnieks, un īpašniekam bija ekskluzīvas tiesības, t. i., tiesības atvairīt visus citus ìpašuma pretendentus un pat iznīcināt savu lietu, nerēḳinoties ar citām personām un sabiedrības interesēm [1,103-104]. Jaunrades rezultāts antīkajā pasaulē netika uzskatìts par īpašumtiesību objektu, un tam tika pieškirta sakrāla nozīme.

Atbilstoši juridiskajā doktrīnā norādìtajam patentu tiesību, tajā skaitā arī patentu ìpašuma, likumiskas aizsardzības pirmsākumus saistāms ar 1474. gada Venēcijas Republikas Statūtiem par rūpnieciskajiem izgudrojumiem. Šā tiesību akta nozīmība ir saistāma ar to, ka tas ir uzskatāms par pirmo normatīvo aktu, pamatojoties uz kuru piešḳirts patents. Atbilstīgi iepriekš pastāvošajai praksei patenti tika pieškirti kā atsevišḳi piešḳirumi un bija saistāmi nevis ar normatīvo regulējumu, bet ar amatpersonu varas īstenošanu. Turklāt Venēcijas Republikas Statūti par rūpnieciskajiem izgudrojumiem paredz tādus patentu īpašuma elementus, kas ir pamatā arī mūsdienu patentu îpašuma tiesībām, piemēram, (a) terminēts (desmit gadi) izgudrojuma monopolstāvoklis patenta īpašniekam; (b) tiesības vērsties tiesā par patenta aizskārumu; (c) tiesības nodot no patenta izrietošās tiesības trešajām personām [2, 9-13].

Rūpnieciskā revolūcija radīja jaunu sociālekonomisko situāciju, kas bija priekšnoteikums arī patenta īpašuma regulējuma pilnveidei. Lielbritānijas 1852. gada Patentu likums akcentēja patentu tiesības kā rūpniecisko ìpašumu. 
Pamatatziṇa, kas izkristalizējās patentu īpašuma regulējuma pilnveidē šajā posmā, ir tāda, ka izgudrojums ir jānošḳir no atklājuma, jo izgudrojums ir jaunrades process, savukārt atklājums saistāms ar jau pastāvošā atklāšanu.

Atklājums noskaidro kaut ko tādu, kas jau dabā eksistēe, proti, parādības, to īpašības un cēloṇus. Izgudrojums turpretĩ ir šādu zināšanu izmantošana, lai apmierinātu sociālu vajadzību [5, 78]. Rūpnieciskās revolūcijas rezultātā monopoltiesības uz izgudrojumu vistiešākajā veidā tika saistītas ne tikai ar izgudrojumu kā tādu, bet arī ar iespēju to rūpnieciski izmantot. Līdz ar to juridiskajā doktrīnā ir pausts viedoklis, ka mūsdienīgas patentu sistēmas izveidošana ir datējama ar 1852. gadu, kad iznāca pirmais patentu likums Lielbritānijā [5, 76]. Šādas paradigmas, kas uzsvēra patenta rūpnieciskās izmantošanas nozīmi un sekmēja patenta īpašuma atzîšanu, noteica arī tas, ka attīstījās ekonomiskie sakari starp valstīm rūpniecības jomā un nozīmīgāka kḷuva arī citās valstīs esošo tiesību aizsardzība. Sākotnējā posmā citu valstu patentu tiesību neievērošana deva iespēju izmantot citās valstīs radītus izgudrojumus un nemaksāt patentmaksu.

Pamatatziṇas, kas saistītas ar patentu īpašumu un industriālās revolūcijas radītajām paradigmām, nostiprinātas 1883. gada 20. marta Parīzes Konvencijā par rūpnieciskā īpašuma aizsardzību [14]. Parīzes Konvencija par rūpnieciskā īpašuma aizsardzību ir uzskatāma par pirmo nozīmīgo dokumentu, kas sniedza ieguldījumu patentu īpašuma unifikācijā.

\section{Eiropas Patentu konvencijas radītā patentu īpašuma aizsardzības sistēma}

Būtisks posms patentu īpašuma tiesību unifikācijā ir saistāms ar 1973. gada 5. oktobra Konvencijas par Eiropas patentu pieškiršanu (Eiropas Patentu konvencija) pien̦emšanu [15].

Eiropas Patentu konvencija nostiprināja vienotu pieeju patentu ỉpašuma izpratnē Eiropas reǵionā. Tajā pašā laikā ir jāuzsver, ka šādas sistēmas izveides pamatā ir valstu brīvprātīga pievienošanās Eiropas Patentu konvencijai, turklāt attiecībā uz Eiropas patentu pastāv izvēles tiesības: var lūgt Eiropas patentu pieškirt attiecībā uz vienu vai vairākām dalībvalstīm. Patenta iedzīvināšanai konkrētas valsts teritorijā ir nepieciešama arī konvencijas dalībvalsts rīcība. Šobrīd Eiropas Patentu konvencijas dalībvalstis ir visas 28 Eiropas Savienības dalībvalstis, kā arī Eiropas Brīvās tirdzniecības līguma asociācijas dalïbvalstis un devinas Eiropas valstis, kas nav ne Eiropas Savienības, ne Eiropas Brīvās tirdzniecības līguma asociācijas dalïbvalstis.

Tomēr Eiropas Savienība nav Patentu konvencijas dalībniece. Ar Eiropas Patentu konvenciju ir nodibināta Eiropas Patentu organizācija, kurai ir juridiskās personas statuss un kuras uzdevums ir piešķirt Eiropas patentu. Eiropas Patentu konvencijā ir iekḷauta arī patentu materiālās tiesības, nosakot priekšnoteikumus patenta īpašuma iegūšanai. Konstitutīvais pamats patenta īpašuma iegūšanai ir saistîts ar izgudrojuma rūpniecisko izmantošanu, novitāti un izgudrojuma līmeni, kā arī ar patenta reǵistrāciju. 
Eiropas Patentu konvencijā uzskaitīiti objekti, kas nav uzskatāmi par izgudrojumiem un tādējādi nav arī patentu ippašuma objekti. Proti, par izgudrojumiem neuzskata: (a) atklājumus, zinātniskās teorijas un matemātikas metodes; (b) estētiskus risinājumus (dizaina paraugus); (c) intelektuālu darbu veikšanas, komercdarbības realizēšanas vai spẹḷ spēlēšanas shēmas, noteikumus un paṇēmienus, kā arī datorprogrammas; (d) informācijas sniegšanas pañēmienus.

Cilvēka vai dzīvnieku terapeitiskās vai ḳirurğiskās ārstēšanas un diagnostikas metodes, kas tiek veiktas ar cilvēka vai dzīvnieku ḳermeni, neuzskata par izgudrojumiem, kurus var rūpnieciski izmantot. Šo noteikumu neattiecina uz produktiem, arī uz vielām vai vielu kompozīcijām, kuras izmanto šajās metodēs.

Eiropas Patentu konvencijā ir noteikti arī izṇēmumi no patentu aizsardzības, proti, Eiropas patentu nepiešksir: (a) izgudrojumiem, kuru publiskošana vai izmantošana ir pretrunā ar sabiedrisko kārtību vai morāli (ordre public), taču šādu lēmumu nedrīkst pien,emt, pamatojoties tikai uz faktu, ka šāda izmantošana ir aizliegta ar likumu vai administratīvo aktu dažās vai visās dalībvalstīs; (b) augu vai dzīvnieku šḳirnēm vai biolog̣iskiem augu un dzīvnieku šḳirṇu iegūšanas paṇēmieniem.

Lai arī Eiropas Patentu konvencijai ir pievienojušās gan Eiropas Savienības dalībvalstis un Eiropas Brīvās tirdzniecības asociācijas dalībvalstis, pati Eiropas Savienība kā juridiska persona nav Eiropas Patentu konvencijas dalïbvalsts, un Eiropas Patentu konvencija nespēj atrisināt jautājumus, kas saistīti ar patenta īpašnieka izṇēmuma tiesībām un Eiropas Savienības kopējo tirgu.

\section{Eiropas Savienības patentu īpašuma aizsardzības sistēma}

Patentu īpašums sākotnēji ir atstāts nacionālo dalībvalstu ziṇā $[3,276]$. Atbilstīgi Eiropas Kopienas dibināšanas līguma 295. pantā noteiktajam šis līgums nekādā veidā neietekmē dalībvalstu îpašuma tiesību sistēmas [6]. Tajā pašā laikā intelektuālā îpašuma tiesību ekskluzivitātei ir neapstrīdams iespaids uz preču un pakalpojumu brīvu apriti. Proti, patenta īpašnieks var liegt importēt preci vai pakalpojumu, ko aizsargā viṇam piederošās intelektuālā īpašuma tiesības, tikai tāpēc, ka šì persona nevēlas šādu preču laišanu tirgū kādā teritorijā. Patenta ìpašnieks var izmantot patenta tiesību spēkā esamību noteiktā teritorijā, lai sadalìtu tirgu $[4,172]$.

Lai atrisinātu patentu īpašuma un brīvas preču kustības kolīziju, Eiropas Kopienu Tiesa, pirmkārt, nošḳīra patentu ìpašuma tiesības no patentu īpašuma tiesību izmantošanas un, otrkārt, definēja "tiesību izsmelšanas principu".

Lietā Parke, Davis v. Probel [19] Eiropas Kopienu Tiesa norādīja, ka pats fakts, ka kādam pieder intelektuālā īpašuma tiesības, nebūt nenozīmē, ka tas ir pretrunā ar Eiropas Kopienas dibināšanas līguma noteikumiem. Intelektuālā īpašuma izmantošanu neatbilstošā veidā var uzskatīt par Eiropas Kopienas tiesību normu pārkāpumu. Turklāt neatbilstoša tiesību izlietošana ir saistāma ar Eiropas Kopienas dibināšanas līguma 
81. pantā minētajām darbībām [10], proti, saskan,otu darbību veikšana, kas var iespaidot tirdzniecību starp dalïbvalstīm un kuru mērḳis vai sekas ir nepiel̦aut, ierobežot vai izkroplot konkurenci.

Darbības, kas ierobežo vai izkropḷ konkurenci:

1) tieša vai netieša iepirkuma vai pārdošanas cenas noteikšana;

2) tirgus, tehnikas attīstības vai investīciju ierobežošanas vai ražošanas kontrole;

3) tirgus vai piegādes avotu sadalī̌ana;

4) līdzvērtīgos darījumos ar dažādiem tirdzniecības partneriem atšḳirīgu noteikumu piemērošana, tādējādi radot tiem neizdevīgus konkurences apstākḷus;

5) slēdzot līgumus, prasību izvirzīšana, lai otra puse uzn,emtos papildu saistības, kuras pēc savas būtỉbas vai saskaṇā ar nozares praksi nekādi nav saistītas ar attiecīgo līguma priekšmetu.

Ekskluzīva izgudrojuma tiesību izmantošana nav vienīgais veids, kā iespējams kontrolēt izgudrojuma tirgu. To var nodrošināt ar produkta ieviešanu agrāk par konkurentiem, ar ražotāja labo slavu, ar ražotāja atpazīstamību (preču zīme, reklāma u. tml.) $[2,37]$. Tomēr jāatzīst, ka ekskluzìvo tiesību izmantošana noteiktā teritorijā neizbēgami radītu pretrunas ar kopējā Eiropas Savienības tirgus ideju un apdraudētu tā darbību.

Lietā Centrafarm BV end Adriaan de Peijper v. Sterling Drug Inc. [20] patenta īpašuma esamība ir attaisnota ar to, ka izgudrotājam ir jāgūst atlīdzība par savām radošajām pūlēm. Patenta īpašuma saturs, Eiropas Kopienu Tiesas ieskatā, aptver patenta īpašnieka tiesības ekskluzìvi: (a) lietot izgudrojumu, izmantojot to tiešā veidā vai pieškirot licences trešajām personām; (b) ražot rūpniecisku produkciju, (c) pirmo reizi laist rūpniecisko produkciju apgrozībā; (d) protestēt pret iepriekš minēto tiesību pārkāpumu. Šajā spriedumā Eiropas Kopienu Tiesa ir formulējusi piekrišanas doktrīnu, proti, izdarījusi secinājumu, ka, sākotnēji izvietojot preci Eiropas Kopienas kopējā tirgū vienā dalībvalstī, patenta īpašnieks ir devis piekrišanu preces izvietošanai kopējā tirgū. Tādējādi, izvietojot preci, kas ir aizsargāta ar patentu vienā dalībvalstī, patenta īpašnieks ir izsmēlis savas ekskluzīvās tiesības aizliegt preces izvietot citur kopējā tirgū.

Formulējot "tiesību izsmelšanas principu", Eiropas Kopienu Tiesa intelektuālā īpašuma tiesību un brīvas preču kustības kolīziju ir atrisinājusi par labu brīvai preču kustībai Eiropas Savienībā. Tiesību izsmelšanas princips nav absolūts, jo, lai uz to atsauktos, ir nepieciešams konstatēt, ka patenta īpašnieks vai tā pilnvarota persona ir devusi sākotnējo piekrišanu produkta izvietošanai tirgū, turklāt tas neattiecas uz trešajām valstīm.

Diskutabls ir jautājums par atḷaujas sniegšanu kā gribas izpausmi vai juridisku fikciju. Eiropas Kopienu Tiesa ir devusi priekšroku juridiskai fikcijai, kas rezultējas tajā, ka patenta īpašnieks nevar norādìt, ka aț̣auju produkta izvietošanai tirgū ir devis tikai vienā Eiropas Savienības dalībvalstī un nav devis piekrišanu izgudrojuma, kas aizsargāts ar patentu, izvietošanai Eiropas Savienības kopējā tirgū.

Kā konkurenci ierobežojošu noteikumu Eiropas Savienības tiesa ir atzinusi tāda noteikuma iekḷaušanu licences līgumos, kas nosaka, ka licenciāts (licences saṇēmējs) neapstrīdēs licenciāra (licences devēja) tiesības uz patentu, kā arī neveiks ieguldījumus izpētē, 
lai rastu jaunus risinājumus, kas l̦autu neizmantot patentēto izgudrojumu. Šāda pieeja sākotnēji tika nostiprināta judikatūrā lietā Windsurfing International INC. v. Commission [21] un vēlāk arī normatīvi Regulā Nr. 2349/84 [7].

Patentu îpašuma un Eiropas Savienības iekšējā tirgus brīvas preču kustības kolīzija pastiprināja nepieciešamību pēc patentu īpašuma tiesiskā regulējuma unifikācijas un harmonizācijas.

Eiropas Savienībā mēǵinājums unificēt un harmonizēt patentu īpašuma tiesisko regulējumu ir saistāms ar 1975. gada Konvenciju par Kopienas patentu [16].

Tajā pašā laikā ir jāuzsver, ka Konvencija par Kopienas patentu netika ratificēta pilnā apmērā; Eiropas Komisija 1997. gadā atzina, ka konvencijas īstenošanā nav sasniegts progress, un sāka apsvērt iespēju izdot regulu, pamatojoties uz Eiropas Kopienas dibināšanas līguma 308. pantu [3, 288].

Atbilstoši Eiropas Kopienas dibināšanas līguma 308. pantam, ja izrādās, ka Kopienai, lai sasniegtu kādu tās mērḳi kopējā tirgus darbībā, jārīkojas, bet šis līgums nepiešḳir vajadzīgās pilnvaras, Padome pēc Komisijas priekšlikuma, apspriedusies ar Eiropas Parlamentu, ar vienprātīgu lēmumu veic attiecīgus pasākumus.

Attiecīgo pasākumu rezultāts:

1) Eiropas Parlamenta un Padomes 2012. gada 17. decembra Regulas Nr. 1257/2012 pieņemšana, ar ko īsteno ciešāku sadarbību attiecībā uz vienotas patentaizsardzības izveidi [9];

2) Eiropas Parlamenta 2012. gada 17. decembra Regulas Nr. 1260/2012 pienemšana, ar ko īsteno ciešāku sadarbību attiecībā uz vienotas patentaizsardzības izveidi, ciktāl tas attiecas uz piemērojamo tulkošanas kārtību [12];

3) Vienotas patentu tiesas izveides nolīguma izstrāde un šã nolīguma ratifikācija [13].

Vienotā spēka Eiropas patentam ir šādas būtiskākās atšḳirības no Eiropas vienotā patenta, kas ieviests ar Eiropas Patentu konvenciju:

1) vienotā spēka Eiropas patentu centralizēti piešḳir Eiropas patentu iestāde, un patenta spēkā esamība nav saistāma ar nepieciešamību to apstiprināt katrā dalībvalstī;

2) dalībvalstis, kurās būs ieviests vienotā spēka Eiropas patents, būs nodevušas kompetenci tiesvedībā patentu strīdos vienotajai un specializētajai patentu tiesai. Vienotā spēka Eiropas patenta ieviešana ir saistīta ar Vienotās patentu tiesas nolīguma ratifikāciju. Tādā veidā iecerēts novērst arī paralēlos tiesvedības procesus patentu strīdos vairākās dalībvalstīs. Paralēlas tiesvedības nepiel̦aušana novērš arī iespēju pien̦emt atšķirīgus lēmumus par vienu un to pašu patentu strīdu;

3) vienotā spēka Eiropas patenta ieviešana iezīmē arī pāreju uz elektronisku dokumentu apriti un automatizētu patentu pieteikumu dokumentācijas tulkošanu. 
Vienotā spēka Eiropas patenta ieviešana vistiešākajā veidā ir saistīta ar Vienotās patentu tiesas nolīguma ratifikāciju. Šobrīd 26 Eiropas Savienības dalībvalstis ir ratificējušas Vienotās patentu tiesas nolīgumu. Spānija un Horvātija nav Vienotās patentu tiesas nolīguma dalībnieces. Eiropas Savienības Tiesas lēmumi būs saistoši arī Vienotajai patentu tiesai, tādējādi nodrošinot Eiropas Savienības tiesību pārākuma principa iedzīvināšanu.

\section{Pasaules Tirdzniecības organizācijas patentu īpašuma aizsardzības sistēma}

Eiropas Savienība ir Marakešas līguma par Pasaules Tirdzniecības organizācijas izveidošanu dalībniece, tāpēc no Marakešas līguma izrietošās saistības ir saistošas arī Eiropas Savienībai kā juridiskai personai. Šĩ ir būtiska atškirīība no situācijas ar Eiropas Patentu konvenciju, kuru ir ratificējušas Eiropas Savienības dalībvalstis, bet nav ratificējusi Eiropas Savienība kā juridiska persona.

Pasaules Tirdzniecības organizācijā Eiropas Savienība darbojas kā viena dalībvalsts, un to pārstāv Eiropas Komisija, nevis dalībvalstis [22, 3].

Līgumā par intelektuālā īpašuma tiesībām saistībā ar tirdzniecību: Marakešas līguma par Pasaules Tirdzniecības organizāciju izveidošanu 1.C pielikumā [11] ir iekḷauts regulejjums patentu aizsardzībai.

Atbilstoši līguma noteikumiem dalībvalstis var izslēgt no patentējamo izgudrojumu saraksta: (a) diagnostikas, terapijas un ḳirurǵiskās metodes cilvēku vai dzīvnieku ārstēšanai; (b) augus un dzīvniekus (ne mikroorganismus) un biologiskos procesus augu vai dzīvnieku producēšanai, kas nav nebiolog̣iski un mikrobiologiski. Tomēr dalībvalstis nodrošina augu sugu aizsardzību ar patentu vai ar efektīvas sui generis sistēmas palīdzību, vai arī ar abu šo sistēmu kombināciju.

Atbilstoši līguma 28. panta noteikumiem patents dod tā ipašniekam šādas ekskluzīvas tiesības: (a) ja patenta saturs ir izstrādājums - nelaut trešajām personām bez īpašnieka piekrišanas izgatavot, lietot, piedāvāt tirdzniecībai, pārdot vai importēt šos izstrādājumus; (b) ja patenta saturs ir process - neḷaut trešajām pusēm bez ìpašnieka piekrišanas izmantot šo procesu, piedāvāt tirdzniecībai, pārdot vai importēt izstrādājumu, kas iegūts tieši šì procesa rezultātā. Patenta ỉpašniekam ir tiesības pieškirt patentu citai personai vai nodot to pēctecības kārtībā un noslēgt attiecīgus licences līgumus. Dalībvalstis var pieprasìt no patenta pieteikuma iesniedzēja informāciju par autora attiecīgajiem iesniegumiem ārvalstīs un tur piešķirtajiem patentiem.

Eiropas Savienības dalība Pasaules Tirdzniecības organizācijā ir raisijjusi arī diskusijas par patentu ỉpašuma tvērumu un morāli ētiskajiem aspektiem patentu īpašuma piešķiršanā un iespējām patenta īpašuma tiesības izlietot. Tādējādi Eiropas Savienības Tiesai ir nācies risināt juridiskus kāzusus par Līguma par intelektuālā īpašuma tiesību saistībā ar tirdzniecību saistību ievērošanu un Direktīvas 98/44/EK par izgudrojumu tiesisko aizsardzību biotehnologijā [8] îstenošanu. 
Iepriekš minēto juridisko kāzusu cēlonis ir saistīts ar šādiem apstākḷiem:

1) Eiropas Savienība ir Pasaules Tirdzniecības organizācijas dalïbniece, un tai ir pienākums ievērot uzṇemtās starptautiskās saistības;

2) Amerikas Savienotajās Valstīs ir atšḳirīga pieeja patentspējas kritēriju izvērtēšanā:

a) Amerikas Savienotajās Valstīs piešḳir patentus arī par tā sauktajām biznesa metodēm. Nedz kontinentālajā Eiropā, nedz arī valstīs, kur darbojas angloamerikāṇu tiesību sistēma, izṇemot Amerikas Savienotās Valstis, biznesa metodes netiek atzìtas par patentspējīgu izgudrojumu. Kontinentālajā Eiropā izgudrojums ir jauns, ja tam piemìt novitāte. Savukārt Amerikas Savienotajās Valstīs tiek izmantots "acīmredzamības kritērijs", proti, izgudrojums nav jauns, ja tas ir acìmredzams [5, 76];

b) biotehnologisko patentu jomā, vērtējot biotehnologisko izgudrojumu patentspēju, ir izteikta utilitāristiska pieeja. Lìdz ar to morāles un ètikas apsvērumiem ir mazāka loma patentspējas kritēriju izvērtējumā kā Rietumu tiesību loka romāṇu-gerermāṇu tiesību saimes valstīs.

Morāles un ètikas apsvērumus Eiropas Savienības Tiesa ir vērtējusi kontekstā ar izgudrojuma novitāti. Novitātes kritērijs Eiropas Savienības Tiesas judikatūrā tiek konfrontēts arī ar ètikas un morāles apsvērumiem, piemēram, prejudiciālā nolēmuma lietā International Stem Cell Corporation vs. Comptroller General of Patents [18] Eiropas Savienības Tiesa ir secinājusi, ka Direktīvas 98/44 par izgudrojumu tiesisko aizsardzību biotehnologijā 6. panta 2. punkta c) apakšpunkts ir jāinterpretē tādējādi, ka neapauglotota cilvēka olšūna, kuras dalī̌nanās un tālāka attīstība ir tikusi stimulēta ar partenogenēzi, nav "cilvēka embrijs" šīs tiesību normas izpratnē, ja, ņemot vērā pašreizējās medicīniski zinātniskās atziṇas, tai nav piemìtošā spēja attīstìties par cilvēku, kas ir jāpārbauda valsts tiesai. Saistībā ar morāles un ètikas normu noteikto redukciju novitātes izmantošanas iespējai Eiropas Savienības Tiesa ir secinājusi, ka izgudrojums nav patentējams, ja patentējamās tehniskās procedūras ieviešanai iepriekš tiek prasīta vai nu cilvēka embriju iznīcināšana, vai to izmantošana par izejmateriālu, pat ja šã procesa aprakstā nav nekādas atsauces uz cilvēka embriju izmantošanu. Jēdziens "cilvēka embrijs" tiek piemērots totipotentām pirmšūnām no to apaug̣̣ošanas brīža, kā arī visam cilvēka ḳermeña attīstības un veidošanās procesam, kas no tā izriet. Neapauglotas olšūnas, kurās implantēts nobriedušas cilvēka šūnas kodols vai kuras tiek dalītas vai attīstās partenogenēēzes ceḷā, arī ietilpst cilvēka embrija jēdzienā, ciktāl šo paneēmienu rezultātā tiek iegūtas totipotentas šūnas. Šādas atziṇas ir sniegtas gan generāladvokāta İva Bota (Yves Bot) atzinumā [23] lietā Oliver Brüstle vs. Greenpeace [17], gan iekḷautas šã sprieduma motīvu dạ̦ā, gan, izmantojot gadījumu salīdzināšanas un tipizēšanas metodi, nostiprinātas turpmākajā Eiropas Savienības Tiesas judikatūrā. 


\section{Secinājumi}

1. Antīkā pasaule nepazina intelektuālā īpašuma jēdzienu, tādējādi romiešu klasiskās tiesības nevar būt par avotu patentu îpašuma izpētē.

2. Patentu īpašuma normatīvā regulējuma rašanās ir saistāma ar 1474. gada Venēcijas Republikas Statūtiem par rūpnieciskajiem izgudrojumiem. Venēcijas Republikas Statūti par rūpnieciskajiem izgudrojumiem normatīvā veidā atzina, ka izgudrojums var būt īpašumtiesību objekts. Statūtos fiksēti patenta ìpašuma pamatelementi, kas veido patenta būtību arī mūsdienās: (a) noteiktas izṇēmuma tiesības izgudrotājam; (b) limitēts izṇēmuma tiesību jeb patenta îpašuma laiks; (c) paredzētas iespējas nodot patentu trešajām personām - izsniegt licenci; (d) tiesības celt prasību tiesā par patenta īpašuma pārkāpumu.

3. Rūpnieciskās revolūcijas ietekmē 18. gadsimta beigās un 19. gadsimta sākumā tika uzsvērta nepieciešamība patentu izmantot rūpnieciski, kas ir neatṇemams patenta īpašuma elements arī mūsdienās.

4. 20. gadsimta otrajā pusē un 21. gadsimta pirmajā pusē nozīmīgākie patentu ìpašuma jautājumi ir saistāmi ar:

a) patentu īpašuma normatīvā regulējuma unifikāciju un harmonizāciju;

b) morāles un ētikas normu piemērošanu patenta îpašuma atzī̌̌anā.

5. Utilitārisma pieeja patentspējas novitātes kritērija izpildē nav absolūta. Eiropas Savienības Tiesa, pamatojoties uz morāles un ētikas apsvērumiem, ierobežo novitātes centienu izpausmes, it īpaši biotehnologisko patentu jomā.

6. Novitāte ir generālklauzula, kuras konkretizēšanā tiesību piemērotājam ir jāveido aksiolog̣iskās premisas. Aksioloǵisko premisu veidošana ir tiesību piemērotāja pienākumus, lai konkrētajā lietā nolēmums būtu leǵitīms. Ėtiskos un morālos apsvērumus Eiropas Savieníbas Tiesa un Eiropas Patentu valde izmanto, lai tehnisku un funkcionālu novitāti reducētu, tādējādi novitātes jēdzienu padarot nevis par fakta, bet tiesību jautājumu.

7. Lai nodrošinātu Eiropas Savienības kopējā tirgus īstenošanu, Eiropas Savienības Tiesa ir formulējusi patenta īpašuma "tiesību izsmelšanas" principu. Tādējādi intelektuālā īpašuma un brīvas preču kustības kolīzija ir atrisināta par labu brīvai preču kustībai Eiropas Savienībā. Patentu īpašuma un Eiropas Savienības iekšèjā tirgus un brīvas preču kustības kolīzija pastiprina nepieciešamību pēc patentu īpašuma tiesiskā regulējuma unifikācijas un harmonizācijas. 


\section{Genesis and Development Perspectives of the Patent Property}

\section{Abstract}

The article provides an insight into the establishment and historical development of the patent property, as well as has emphasises the present development trends in the area of the patent property.

The author has systematised historical development stages of the patent property, as well as emphasised circumstances that changed the understanding of the patent property.

The article analyses the establishment of protection systems of the patent property and peculiarities thereof. It analyses solutions of impact in the field of the patent property, arising due to the fact that one country may have undertaken liabilities within the framework of several international agreements. The author has emphasised also the meaning of moral and ethical norms in the area of the patent property as well as has persuasively showed the meaning of moral and ethical norms in recognition of patent property by samples from case law.

Keywords: ethics, property, patent, unification of rights.

\section{Avoti un literatūra}

\section{Literatūra}

1. Kalniņš, V. Romiešu civiltiesību pamati. Rìga: Zvaigzne, 1977.

2. Markvarts, R. Intelektuālā ìpašuma teoriju nozìme patenttiesību attīstībā. Rìga, [b. i.], 2013.

3. Penelope, K. Law of the European Union. London: Pearson Education Limited, 2001.

4. Raihs, N. Izprotot Eiropas Savienības tiesības. Rīga: Tiesu namu aǵentūra, 2004.

5. Rozenfelds, J. Intelektuālais ìpašums. Rìga: Zvaigzne ABC, 2004.

\section{Normativie akti}

6. Amsterdamas līgums (kas groza Eiropas Savienības līgumu, Eiropas Kopienu dibināšanas lïgumus un ar tiem saistitos aktus. OJEC 340, 10/11/1997.

7. Commission Regulation (EEC) No. 2349/84 of 23 July 1984 on the application of Article 85 (3) of the Treaty to certain categories of patent licensing agreements. OJEC 16.8.84. No. L219/15.

8. Eiropas Parlamenta un Padomes 1998. gada 6. jūlija Direktīva 98/44/EK par izgudrojumu tiesisko aizsardzību biotehnolog̣ijā. OJ L 213, 30.07.1998.

9. Eiropas Parlamenta un Padomes 2012. gada 17. decembra Regula (ES) Nr. 1257/2012, ar ko isteno ciešāku sadarbību attiecībā uz vienotas patentaizsardzỉbas izveidi. Eiropas Savienības Oficiälais Vēstnesis. L 361/1, 31.12.2012.

10. Konsolidēts Eiropas Kopienas dibināšanas līgums un Nicas līgums. Rīga: TTC, 2001. 
11. Līgums par intelektuālā īpašuma tiesībām saistībā ar tirdzniecību: Marakešas līguma par Pasaules Tirdzniecības organizācijas izveidošanu 1.C pielikums, parakstīts 1994. gada 15. aprīlī. Latvijas Vēstnesis. 388, 30.12.1998.

12. Padomes 2012. gada 17. decembra Regula Nr. 1260/2012, ar ko ìsteno ciešāku sadarbību attiecībā uz vienotas patentaizsardzības izveidi, ciktāl tas attiecas uz piemērojamo tulkošanas kārtību. Eiropas Savienības Oficiālais Vēstnesis. L 361/89, 31.12.2012.

13. Par Vienotās patentu tiesas izveides nolīgumu. Latvijas Vēstnesis. 75 (5902), 12.04.2017.

14. 1883. gada 20. marta Parīzes Konvencija par rūpnieciskā īpašuma aizsardzību. Latvijas Vèstnesis. 54 (2819), 08.04.2003.

15. 1973. gada 5. oktobra Konvencija par Eiropas patentu piešķiršanu (Eiropas Patentu konvencija). Latvijas Vèstnesis. 43 (3201), 15.03.2005.

16. 1975. gada 15. decembra Konvencija par Kopienas patentu, OJ 1976, L 17, 1. lpp.

\section{Tiesu prakse}

17. Eiropas Savienības Tiesas (virspalātas) 2011. gada 18. oktobra spriedums lietā Oliver Brüstle v. Greenpeace eV. Lieta C-34/10. Lūgums sniegt prejudiciālu nolēmumu: Bundesgerichtshof Vācija. Direktīva 98/44/EK - 6. panta 2. punkta c) apakšpunkts - Biotehnoloǵisko izgudrojumu tiesiskā aizsardzība. Pirmšūnu iegūšana no cilvēka embrionālajām cilmes šūnām, to patentspēja. Cilvēka embrija izmantošanas rūpnieciskiem vai komerciāliem mērḳiem izslēgšana. Eiropas Savienības Tiesas Ziṇotājs. 2011 1-09821. ECLI identifikators: ECLI:EU:C:2011:669.

18. Eiropas Savienības Tiesas (virspalātas) 2014. gada 18. decembra spriedums lietā C-364/13. Lūgums sniegt prejudiciālu nolēmumu - Direktīva 98/44/EK - 6. panta 2. punkta c) apakšpunkts - Biotehnologisko izgudrojumu tiesiskā aizsardzība - Aktivēšana ar olšūnu partenoǵenēzi - Cilvēka embrionālo cilmes šūnu ražošana - Patentspēja - "Cilvēka embrija izmantošanas rūpnieciskiem un komerciāliem mērḳiem” izslēgšana - Jēdzieni "cilvēka embrijs" un "organisms, ar kuru var tikt aizsākts cilvēka attīstības process". Lūgums sniegt prejudiciālu nolēmumu atbilstoši LESD 267. pantam, ko High Court of Justice (England E Wales), Chancery Division (Patents Court) (Apvienotā Karaliste) iesniedza ar lēmumu, kas pieñemts 2013. gada 17. aprīlī un kas Tiesā reǵistrēts 2013. gada 28. jūnijā, tiesvedībā International Stem Cell Corporation v. Comptroller General of Patents, Designs and Trade Marks. ECLI identifikators EU:C:2014:2451.

19. Judgment of the Court of 29 February 1968. Parke, Davis and Co. v. Probel, Reese, BeintemaInterpharm and Centrafarm. Case 24-67. English Special Edition. 196800055 ECLI identifier: ECLI: EU: C1968:11.

20. Judgment of the Court of 31 October 1974. Centrafarm BV and Adriaan de Peijper v. Sterling Drug Inc. Case 15-74. European Court Reports. 1974 - 01147. ECLI identifier: ECLI: EU: 1974: 114.

21. Judgment of the Court (Fourth Chamber) of 25 February 1986. Windsurfing International Inc. v. Commission of the European Communities. Agreements prohibited by Article 85 of the EEC Treaty. Case 193/83. European Court Reports. 1986-00611. ECLI identifier: ECLI:EU:C:1986:75. 


\section{Interneta resursi}

22. Eiropas Savienība un Pasaules Tirdzniecības organizācija. Iegūts no: http://www.europarl. europa.eu/ftu/pdf/lv/FTU_6.2.2.pdf [sk. 14.04.2017.].

23. G̦enerāladvokāta İva Bota (Yves Bot) atzinums lietā Nr. C-34/10 Oliver Brüstle vs. Greenpeace eV. Iegūts no: http://curia.europa.eu/juris/document/document.jsf?text=patentsp\%25C4\%2593j a\&docid=81836\&pageIndex=0\&doclang $=$ LV\& mode $=$ req \&dir $=\&$ occ $=$ first $\&$ part $=1 \&$ cid $=587$ 935\#ctx1 [sk. 14.04.2017.]. 